\title{
Review Article \\ The Application of Stem Cells from Different Tissues to Cartilage Repair
}

\author{
James N. Fisher, ${ }^{1}$ Irene Tessaro, ${ }^{1}$ Tommaso Bertocco, ${ }^{2}$ Giuseppe M. Peretti, ${ }^{1,3}$ \\ and Laura Mangiavini ${ }^{1}$ \\ ${ }^{1}$ IRCCS Istituto Ortopedico Galeazzi, 20161 Milan, Italy \\ ${ }^{2}$ Università Vita-Salute San Raffaele, Milan, Italy \\ ${ }^{3}$ Department of Biomedical Sciences for Health, University of Milan, Milan, Italy
}

Correspondence should be addressed to Laura Mangiavini; lauman82@hotmail.it

Received 31 May 2017; Accepted 24 October 2017; Published 10 December 2017

Academic Editor: Bernard A. J. Roelen

Copyright @ 2017 James N. Fisher et al. This is an open access article distributed under the Creative Commons Attribution License, which permits unrestricted use, distribution, and reproduction in any medium, provided the original work is properly cited.

\begin{abstract}
The degeneration of articular cartilage represents an ongoing challenge at the clinical and basic level. Tissue engineering and regenerative medicine using stem/progenitor cells have emerged as valid alternatives to classical reparative techniques. This review offers a brief introduction and overview of the field, highlighting a number of tissue sources for stem/progenitor cell populations. Emphasis is given to recent developments in both clinical and basic sciences. The relative strengths and weaknesses of each tissue type are discussed.
\end{abstract}

\section{Introduction}

Articular cartilage has a poor self-healing potential, mainly due to the lack of vascularisation and the paucity of undifferentiated cells [1]. Thus, if focal cartilage lesions are left untreated, they can progress to more extensive defects and may ultimately require treatment with joint replacement surgery if conservative options fail. The aim of this review is to describe in detail recent findings in both basic and clinical studies that have adapted cells from a variety of cell sources to cartilage repair strategies.

Current treatments for cartilage repair are mainly focused on bone marrow stimulation techniques: such as abrasive chondroplasty, subchondral drilling, microfracture and, more recently, nanofractures [2]. The aim of these techniques is to allow migration to the damaged area and the subsequent chondrogenic differentiation of multipotent bone marrow-derived stromal/stem cells (BMSCs). However, often, the regenerated tissue does not possess the same biochemical and biomechanical properties of the native cartilage; therefore, it is not able to resist the continuous stresses placed upon it, and it quickly degenerates [3]. Hence, new treatment options for articular cartilage lesions have grown in recent decades, due to promising results obtained with the development of new therapeutic options.

Tissue engineering strategies aim to regenerate the damaged tissue and restore a biologically and biomechanically valid articular surface. This requires three components, which may be alternately combined. The first is a suitable cell source which can differentiate into, and maintain, the specific cell phenotype; research in this area forms the body of this review (see Table 1). Additionally, signalling molecules such as growth factors, cytokines, or hormones stimulate cell growth and differentiation, and traditionally, a scaffold is used to provide an adequate three-dimensional environment $[4,5]$, although scaffold-free techniques have also proven successful (reviewed in Shimomura et al. [6]).

Growth factors, cytokines, and hormones are used to stimulate cell proliferation (owing to the low number of endogenous progenitors) and induce chondrocytic differentiation (without inducing hypertrophy or causing transformation) leading to the secretion of a collagen-rich extracellular matrix (ECM). Growth factors exert their effects by binding to, and activating, specific membrane-bound (usually transmembrane) receptors. Ligand binding typically leads to the activation of an intracellular signalling cascade (such as 
TABLE 1: Summary of recent results in the application of stem and progenitor cells to cartilage repair and regeneration.

(a)

\begin{tabular}{|c|c|c|c|c|c|c|}
\hline Author & Year & $\begin{array}{l}\text { Cell } \\
\text { source }\end{array}$ & Model & Experimental study & $\begin{array}{l}\text { Adverse } \\
\text { effects }\end{array}$ & Key findings \\
\hline Shafiee et al. & 2011 & Cartilage & Mice & $\begin{array}{l}\text { Proliferation, tumourigenesis, } \\
\text { and multipotency of nasal } \\
\text { septum-derived adult cells }\end{array}$ & None & $\begin{array}{c}\text { NCs retained chondrogenic potential } \\
\text { until passage } 35 \text {. Markers suggest } \\
\text { chondrogenic ability equal to that of } \\
\text { BMSCs }\end{array}$ \\
\hline do Amaral et al. & 2012 & Cartilage & In vitro & $\begin{array}{c}\text { Proliferation and multipotency of } \\
\text { nasal septal cartilage surface zone } \\
\text { cells within the context of cartilage } \\
\text { repair }\end{array}$ & NA & $\begin{array}{l}\text { Cells in pellet culture resulted in } \\
\text { chondrogenesis without TGF- } \beta \text { or } \\
\text { BMPs. NCs were CD } 105^{+}, \text {CD } 73^{+} \text {, } \\
\text { CD } 44^{+} \text {, and CD } 146^{-}\end{array}$ \\
\hline Pelttari et al. & 2014 & Cartilage & $\begin{array}{l}\text { Humans }(10) \\
\text { mice, goats }\end{array}$ & $\begin{array}{l}\text { Suitability of adult human } \\
\text { neuroectoderm-derived nasal } \\
\text { chondrocytes for articular } \\
\text { cartilage repair }\end{array}$ & None & $\begin{array}{l}\text { NCs proliferated faster and were more } \\
\text { chondrogenic than Acs in vitro. In vivo, } \\
\text { defect filling was observed after } 4 \text { months }\end{array}$ \\
\hline Jiang et al. & 2016 & Cartilage & $\begin{array}{l}\text { Humans (15), } \\
\text { mice }\end{array}$ & $\begin{array}{l}\text { Cartilage repair potential } \\
\text { of resident cartilage } \\
\text { stem/progenitor cells }\end{array}$ & None & $\begin{array}{c}\text { ACs became } \mathrm{CD} 146^{+} \text {in high-density } \\
2 \mathrm{D} \text { culture, and their chondrogenic } \\
\text { potential is similar to that of BMSCs. In } \\
\text { vivo results were promising }\end{array}$ \\
\hline Embree et al. & 2016 & Cartilage & Rats, rabbits & $\begin{array}{l}\text { Potential of single resident } \\
\text { fibrocartilage stem cells (FCSC) to } \\
\text { regenerate cartilage, bone, and } \\
\text { haematopoietic compartment }\end{array}$ & None & $\begin{array}{l}\text { FCSCs spontaneously produced cartilage } \\
\text { anlage in vivo which was then remodeled } \\
\text { into trabecular bone. Addition of } \\
\text { sclerostin maintained the FCSC pool and } \\
\text { led to chondrocyte differentiation and } \\
\text { cartilage repair in vivo }\end{array}$ \\
\hline Fellows et al. & 2017 & Cartilage & In vitro & $\begin{array}{l}\text { Senescence of healthy versus } \\
\text { diseased human knee articular } \\
\text { cartilage rather than regenerative } \\
\text { potential per se }\end{array}$ & NA & $\begin{array}{l}\text { The number of progenitor cells was } \\
\text { greater }(2 \mathrm{x}, P<0.001) \text { in OA tissue than } \\
\text { in healthy cartilage. Subpopulation of } \\
\text { OA-derived cells had reduced } \\
\text { proliferative potential and underwent } \\
\text { early senescence in vitro. An increase in } \\
\text { senescent cells may contribute to the } \\
\text { disease phenotype }\end{array}$ \\
\hline Pittenger et al. & 1999 & $\mathrm{BM}$ & In vitro & $\begin{array}{l}\text { Maintenance of multipotency in } \\
\text { individual adult BMSCs }\end{array}$ & NA & $\begin{array}{l}\text { Adult stem cells can be induced to } \\
\text { differentiate exclusively into adipocytic, } \\
\text { chondrocytic, and osteogenic lineages }\end{array}$ \\
\hline Wakitani et al. & 2004 & $\mathrm{BM}$ & Humans (2) & $\begin{array}{l}\text { Effectiveness of autologous BMSC } \\
\text { transplantation for the repair of } \\
\text { full-thickness articular cartilage } \\
\text { defects in the patellae of } 2 \\
\text { individuals }\end{array}$ & None & $\begin{array}{l}\text { Clinical symptoms (pain \& walking } \\
\text { impediment) were significantly reduced } \\
6 \text { months postop. Benefits remained for } \\
4-5 \text { years. Arthroscopy revealed defects } \\
\text { filled with fibrocartilage }\end{array}$ \\
\hline Wakitani et al. & 2011 & $\mathrm{BM}$ & Humans (41) & $\begin{array}{c}\text { Safety of autologous BMSC } \\
\text { implantation for cartilage defects }\end{array}$ & None & $\begin{array}{c}\text { No tumour or infections reported in any } \\
\text { patient. Five had total knee replacement } \\
\text { due to progression to OA }\end{array}$ \\
\hline Wong et al. & 2013 & $\mathrm{BM}$ & Humans (56) & $\begin{array}{c}\text { Autologous BMSC i.a. injections } \\
\text { with microfracture and tibial } \\
\text { osteotomy }\end{array}$ & None & $\begin{array}{l}\text { The experimental group showed } \\
\text { significantly better IKDC }(P=0.001) \text {, } \\
\text { Tegner }(P=0.021) \text {, MOCART }(P< \\
0.001) \text {, and Lysholm }(P=0.016) \text { scores }\end{array}$ \\
\hline
\end{tabular}

(b)

\begin{tabular}{|c|c|c|c|c|c|c|}
\hline Author & Year & Cell source & Model & What was examined & Adverse effects & Key findings \\
\hline Vangsness et al. & 2014 & $\mathrm{BM}$ & $\begin{array}{c}\text { Humans } \\
\text { (55) }\end{array}$ & $\begin{array}{l}\text { Safety and effects on OA } \\
\text { changes in the knee following } \\
\text { intra-articular injection of } \\
\text { allogeneic human BMSCs }\end{array}$ & None & $\begin{array}{l}\text { Evidence of meniscus } \\
\text { regeneration and improvement } \\
\text { in knee pain following } \\
\text { treatment with allogeneic } \\
\text { human mesenchymal stem cells }\end{array}$ \\
\hline
\end{tabular}


Table 1: Continued.

\begin{tabular}{|c|c|c|c|c|c|c|}
\hline Author & Year & Cell source & Model & What was examined & Adverse effects & Key findings \\
\hline Gobbi et al. & 2014 & $\mathrm{BM}$ & $\begin{array}{c}\text { Humans } \\
\text { (25) }\end{array}$ & $\begin{array}{c}\text { BMAC (BM aspirate } \\
\text { concentrate) for the repair } \\
\text { of large full-thickness knee } \\
\text { cartilage defects }\end{array}$ & None & $\begin{array}{c}\text { Significant improvement in } \\
\text { Tegner, Marx, Lysholm, VAS, } \\
\text { IKDC subjective, and KOOS } \\
\text { scores at the final follow-up } \\
\text { compared with their respective } \\
\text { preoperative scores }(P<0.001) \text {; } \\
\text { MRI analysis at the final } \\
\text { follow-up showed stable } \\
\text { implantation and complete } \\
\text { filling of the defect in } 20 \text { of } 25 \\
\text { patients }\end{array}$ \\
\hline Vega et al. & 2015 & $\mathrm{BM}$ & $\begin{array}{c}\text { Humans } \\
(30)\end{array}$ & $\begin{array}{l}\text { Effects of i.a. injection of } \\
\text { allogeneic BMSC versus } \\
\text { hyaluronic acid for the } \\
\text { treatment of knee OA }\end{array}$ & None & $\begin{array}{l}\text { At 1-year follow-up, cartilage } \\
\text { formation in cell-treated } \\
\text { defects was significantly } \\
\text { improved over control } \\
\text { (HA)-treated defects }\end{array}$ \\
\hline Nakagawa et al. & 2016 & $\mathrm{BM}$ & Rats & $\begin{array}{l}\text { Lubricin expression and } \\
\text { chondrogenesis in BMSCs } \\
\text { using pellets \& hanging-drop } \\
\text { cultures in vitro and in vivo }\end{array}$ & NS & $\begin{array}{l}\text { The treatment group scored } \\
\text { significantly higher than the } \\
\text { control group when assessed } \\
\text { histologically at } 8 \text { and } 12 \text { weeks }\end{array}$ \\
\hline Chen et al. & 2016 & $\mathrm{BM}$ & Rabbits & $\begin{array}{c}\text { PTH-treated versus } \\
\text { untreated BMSCs embedded } \\
\text { in fibrin glue for the repair of } \\
\text { induced articular cartilage } \\
\text { injury in rabbits }\end{array}$ & None & $\begin{array}{l}\text { The ICRS score significantly } \\
\text { increased }(P<0.05) \text { in PTH- } \\
\text { treated versus non-PTH and } \\
\text { untreated groups. Significantly } \\
\text { increased levels of type II } \\
\text { collagen and aggrecan mRNA } \\
\text { and protein in PTH versus } \\
\text { non-PTH groups }(P<0.05)\end{array}$ \\
\hline Shapiro et al. & 2017 & $\mathrm{BM}$ & $\begin{array}{c}\text { Humans } \\
(25)\end{array}$ & $\begin{array}{l}\text { BMAC for the treatment of } \\
\text { knee pain from bilateral } \\
\text { osteoarthritis }\end{array}$ & None & $\begin{array}{l}\text { Knee pain decreased in all } \\
\text { groups, although no significant } \\
\text { difference between BMAC and } \\
\text { saline groups }(P>0.9)\end{array}$ \\
\hline Koga et al. & 2008 & Synovium & Rabbits & $\begin{array}{l}\text { "Local adherent technique" } \\
\text { whereby an i.a. injection of } \\
\text { synovium stem/progenitor } \\
\text { cells adheres to the defect site } \\
\text { within } 10 \text { minutes }\end{array}$ & NA & $\begin{array}{l}\text { Increased cell attachment } \\
\text { correlated with improved } \\
\text { cartilage repair at } 24 \text { weeks. It } \\
\text { was reported that } 60 \% \text { of } \\
\text { injected cells adhered at the site }\end{array}$ \\
\hline Nakamura et al. & 2012 & Synovium & Pigs & $\begin{array}{c}\text { Adherence of synovium- } \\
\text { derived cells to cartilage } \\
\text { defects and effects on } \\
\text { cartilage }\end{array}$ & None & $\begin{array}{l}\text { The cartilage matrix detected } \\
\text { in all treated defects versus } \\
\text { none in the control group. } \\
\text { Wakitani and ICRS scores } \\
\text { were significantly higher in } \\
\text { treatment groups }(P<0.05) \text {. } \\
\text { Higher chondrogenic potential } \\
\text { in synovial cells versus BM, } \\
\text { adipose, muscle, or } \\
\text { periosteum-derived cells }\end{array}$ \\
\hline Sekiya et al. & 2015 & Synovium & $\begin{array}{l}\text { Humans } \\
(10)\end{array}$ & $\begin{array}{l}\text { "Local adherent technique" } \\
\text { using autologous synovium- } \\
\text { derived stem/progenitor cells }\end{array}$ & $\begin{array}{l}1 \text { patient had fibrillation of } \\
\text { repaired cartilage }\end{array}$ & $\begin{array}{l}\text { Transplantation of synovial } \\
\text { cells was deemed effective: } \\
\text { Lysholm and MRI-based } \\
\text { scores increased over } \\
3 \text { years + follow-up period } \\
\text { (both } P=0.005 \text { ) }\end{array}$ \\
\hline Mak et al. & 2016 & Synovium & Mice & $\begin{array}{l}\text { Chondrogenic potential of } \\
\text { synovium-derived sca-1- } \\
\text { positive stem/progenitor cells } \\
\text { injected into injured joint }\end{array}$ & NS & $\begin{array}{l}\text { Intra-articular injection of } \\
\text { Sca- } 1^{+} \mathrm{GFP}^{+} \text {synovial cells } \\
\text { from C57BL6 or MRL/MpJ } \\
\text { "super-healer" mice to C57BL6 } \\
\text { mice following cartilage injury }\end{array}$ \\
\hline
\end{tabular}


TABle 1: Continued.

\begin{tabular}{|c|c|c|c|c|c|c|}
\hline Author & Year & Cell source & Model & What was examined & Adverse effects & Key findings \\
\hline Baboolal et al. & 2016 & Synovium & Dogs & $\begin{array}{l}\text { Role of HA on MSC } \\
\text { attachment to cartilage }\end{array}$ & NS & $\begin{array}{l}\text { led to similar levels of cartilage } \\
\text { repair. Treatment with cells } \\
\text { resulted in cartilage repair that } \\
\text { was significantly greater than } \\
\text { that of untreated defects } \\
\text { It was confirmed that HA } \\
\text { inhibits MSC-cartilage } \\
\text { attachment }\end{array}$ \\
\hline Diekman et al. & 2010 & Adipose & In vitro & $\begin{array}{l}\text { Differences in chondrogenic } \\
\text { potential of ADSC and } \\
\text { BMSC in different culture } \\
\text { conditions }\end{array}$ & NA & $\begin{array}{l}\text { ADSCs and BMSCs require } \\
\text { different in vitro culture } \\
\text { conditions to achieve optimal } \\
\text { chondrogenic outcomes. } \\
\text { While both ADSC and BMSC } \\
\text { underwent chondrogenic } \\
\text { differentiation in all conditions } \\
\text { tested, BMSCs produced a } \\
\text { more matrix over a wider } \\
\text { range of conditions }\end{array}$ \\
\hline Koh et al. & 2013 & Adipose & $\begin{array}{l}\text { Humans } \\
\quad(18)\end{array}$ & $\begin{array}{l}\text { Outcome of i.a. injections of } \\
\text { autologous ADSCs for the } \\
\text { treatment of knee OA }\end{array}$ & $\begin{array}{l}\text { One case of pain and } \\
\text { swelling }\end{array}$ & $\begin{array}{l}\text { Significant reduction in } \\
\text { WOMAC scores }(P>0.001) \\
\text { relative to preop levels. The } \\
\text { Lysholm score increased from } \\
40.1 \text { points to } 73.4 \text { points } \\
(P>0.001) \text {, and the mean VAS } \\
\text { score decreased over the period } \\
\text { of the study from } 4.8 \text { to } 2.0 \\
(P>0.005)\end{array}$ \\
\hline Jo et al. & 2014 & Adipose & $\begin{array}{l}\text { Humans } \\
\text { (18) }\end{array}$ & $\begin{array}{l}\text { Safety and efficacy of i.a. } \\
\text { injections of autologous } \\
\text { ADSC for knee OA }\end{array}$ & None & $\begin{array}{l}\text { Improvements were seen in the } \\
\text { high-dose group } \\
\text { (improvement in WOMAC \& } \\
\text { VAS at } 6 \text { months). Significant } \\
\text { decreases in cartilage defect } \\
\text { size paralleled by an increase in } \\
\text { cartilage volume at some defect } \\
\text { sites at } 6 \text { months }\end{array}$ \\
\hline Koh et al. & 2015 & Adipose & $\begin{array}{l}\text { Humans } \\
\quad(30)\end{array}$ & $\begin{array}{c}\text { Injection of ADSCs and } \\
\text { arthroscopic lavage for knee } \\
\text { OA }\end{array}$ & $\begin{array}{l}\text { Slight knee pain, resolved } \\
\text { with medication }\end{array}$ & $\begin{array}{l}\text { The technique appears to be } \\
\text { effective in cartilage healing, } \\
\text { reducing pain, and improving } \\
\text { function }\end{array}$ \\
\hline Koh et al. & 2016 & Adipose & $\begin{array}{l}\text { Humans } \\
\quad(80)\end{array}$ & $\begin{array}{l}\text { ADSCs with fibrin glue and } \\
\text { microfracture (MFX) versus } \\
\text { MFX alone in patients with } \\
\text { symptomatic knee cartilage } \\
\text { defects }\end{array}$ & NS & $\begin{array}{l}\text { Both treatment groups saw } \\
\text { improvement in multiple } \\
\text { clinical outcomes; however, the } \\
\text { degree of improvement was } \\
\text { greater in patients who } \\
\text { received ADSC in addition to } \\
\text { MFX }\end{array}$ \\
\hline Pers et al. & 2017 & Adipose & $\begin{array}{l}\text { Humans } \\
\text { (18) }\end{array}$ & $\begin{array}{l}\text { Intra-articular injections of } \\
\text { different doses of ADSCs }\end{array}$ & $\begin{array}{l}\text { Unstable angina pectoris } \\
\text { reported in } 1 \text { patient, } 5 \\
\text { minor AEs reported by } \\
\text { four patients potentially } \\
\text { related to the procedure }\end{array}$ & $\begin{array}{c}\text { All dose groups saw an overall } \\
\text { negative trend in WOMAC } \\
\text { (pain, stiffness, and function), } \\
\text { VAS, and SAS, although these } \\
\text { data were significant only in } \\
\text { the low-dose group }\end{array}$ \\
\hline Saw et al. & 2013 & $\begin{array}{l}\text { Peripheral } \\
\text { blood }\end{array}$ & $\begin{array}{l}\text { Humans } \\
\quad(50)\end{array}$ & $\begin{array}{c}\text { Postoperative i.a. injections } \\
\text { of hyaluronic acid with and } \\
\text { without PBSC }\end{array}$ & None & $\begin{array}{l}\text { A nonsignificant }(P=0.8) \\
\text { increase in the IKDC score for } \\
\text { the PBSC group at } 24 \text { months. } \\
\text { A significant }(P=0.013) \\
\text { increase in the MRI score in } \\
\text { the PBSC group at } 18 \text { months }\end{array}$ \\
\hline
\end{tabular}


TABle 1: Continued.

\begin{tabular}{|c|c|c|c|c|c|c|}
\hline Author & Year & Cell source & Model & What was examined & Adverse effects & Key findings \\
\hline Fu et al. & 2014 & $\begin{array}{l}\text { Peripheral } \\
\text { blood }\end{array}$ & Rabbits & $\begin{array}{l}\text { Mobilised rabbit PBSCs } \\
\text { versus rabbit BMSCs for } \\
\text { in vivo chondrogenesis }\end{array}$ & None & $\begin{array}{c}\text { PBSCs showed greater } \\
\text { chondrogenic potential than } \\
\text { BMSCs in vitro, although both } \\
\text { cell types performed equally } \\
\text { well in in vivo assays for } \\
\text { cartilage repair }\end{array}$ \\
\hline Fu et al. & 2014 & $\begin{array}{l}\text { Peripheral } \\
\text { blood }\end{array}$ & $\begin{array}{c}\text { Humans } \\
\text { (1) }\end{array}$ & $\begin{array}{c}\text { Injection of autologous } \\
\text { activated PBSCs }+ \text { autologous } \\
\text { periosteum flap in a chondral } \\
\text { lesion }\end{array}$ & None & $\begin{array}{c}\text { Second-look arthroscopy } \\
\text { showed a smooth surface at } 8 \\
\text { months postoperation. CT and } \\
\text { MRI evaluations showed a } \\
\text { significant improvement } \\
\text { compared to preoperation }\end{array}$ \\
\hline Saw et al. & 2015 & $\begin{array}{l}\text { Peripheral } \\
\text { blood }\end{array}$ & $\begin{array}{c}\text { Humans } \\
(8)\end{array}$ & $\begin{array}{c}\text { Autologous PBSCs and HA } \\
\text { with concomitant medial } \\
\text { open-wedge high tibial } \\
\text { osteotomy }\end{array}$ & None & $\begin{array}{l}\text { At } 25 \text {-month follow-up, } \\
\text { arthroscopy and biopsy } \\
\text { revealed smooth, well- } \\
\text { integrated regenerated tissue } \\
\text { rich in type II collagen and } \\
\text { proteoglycan, with some type I } \\
\text { collagen present }\end{array}$ \\
\hline Ha et al. & 2015 & $\begin{array}{l}\text { Umbilical } \\
\text { cord }\end{array}$ & Minipigs & $\begin{array}{l}\text { Ability of human UBSC cell } \\
\text { lines in HA hydrogel (versus } \\
\text { empty defects) to repair } \\
\text { osteochondral defects }\end{array}$ & None & $\begin{array}{l}\text { Defects which received } \\
\text { cells + HA had more safranin- } \\
\text { O-positive staining, more } \\
\text { regenerated cartilage, and } \\
\text { better integration with the } \\
\text { surrounding tissue. The } \\
\text { IRCS score was better in cell } \\
\text { transplant defects than in } \\
\text { empty defects }\end{array}$ \\
\hline Li et al. & 2016 & $\begin{array}{l}\text { Umbilical } \\
\text { cord }\end{array}$ & In vitro & $\begin{array}{l}\text { It was determined whether } \\
\text { coculture of human ACs } \\
\text { could increase chondrogenic } \\
\text { potential of human UBSCs }\end{array}$ & NA & $\begin{array}{c}\text { Indirect coculture increased } \\
\text { expression of chondrogenic } \\
\text { markers. However, qPCR, WB, } \\
\text { and some 2D IHC data contain } \\
\text { inconsistencies }\end{array}$ \\
\hline $\begin{array}{l}\text { Gomez-Leduc } \\
\text { et al. }\end{array}$ & 2016 & $\begin{array}{l}\text { Umbilical } \\
\text { cord }\end{array}$ & Mice & $\begin{array}{l}\text { Chondrogenic potential of } \\
\text { human UCBSCs seeded on } \\
\text { type I/III collagen sponges } \\
\pm \text { chondrogenic factors }\end{array}$ & NS & $\begin{array}{l}\text { UBSCs cultured in vitro with } \\
\text { TGF- } \beta 1 \text { and BMP-2 were } \\
\text { implanted in nude mice. Cells } \\
\text { exposed to growth factors in an } \\
\text { in vitro phase produced a } \\
\text { cartilaginous matrix rich in } \\
\text { type II collagen. No scaffolds } \\
\text { progressed to calcification but } \\
\text { instead deposited type II } \\
\text { collagen-rich ECM }\end{array}$ \\
\hline Park et al. & 2017 & $\begin{array}{l}\text { Umbilical } \\
\text { cord }\end{array}$ & $\begin{array}{c}\text { Humans } \\
\text { (1) }\end{array}$ & $\begin{array}{l}\text { Transplanted human } \\
\text { UCBSCs in a } 4 \% \text { HA } \\
\text { hydrogel into a rabbit } \\
\text { trochlea defect }\end{array}$ & None & $\begin{array}{l}\text { VAS, IKDC, \& WOMAC } \\
\text { improved. At 1-year follow-up, } \\
\text { second-look arthroscopy and } \\
\text { biopsy showed smooth } \\
\text { safranin-O-positive hyaline- } \\
\text { cartilage with excellent } \\
\text { peripheral integration. MRI } \\
\text { showed defect filling, abundant } \\
\text { repair tissue, and good } \\
\text { integration with the } \\
\text { surrounding tissue }\end{array}$ \\
\hline Park et al. & 2017 & $\begin{array}{l}\text { Umbilical } \\
\text { cord }\end{array}$ & $\begin{array}{c}\text { Humans } \\
\text { (7) }\end{array}$ & $\begin{array}{c}\text { Treatment of a large } \\
\text { osteochondral defect by } \\
\text { autologous UCBSCs in a HA } \\
\text { hydrogel }\end{array}$ & None & $\begin{array}{l}\text { Regenerated tissue was thick, } \\
\text { smooth, and glossy white with } \\
\text { good integration with the } \\
\text { surrounding tissue and }\end{array}$ \\
\hline
\end{tabular}


TABLe 1: Continued.

\begin{tabular}{|c|c|c|c|c|c|c|}
\hline Author & Year & Cell source & Model & What was examined & Adverse effects & Key findings \\
\hline Park et al. & 2017 & $\begin{array}{l}\text { Umbilical } \\
\text { cord }\end{array}$ & Rabbits & $\begin{array}{l}\text { Efficacy of human autologous } \\
\text { UCBSCs and HA hydrogels } \\
\text { for cartilage regeneration }\end{array}$ & None & $\begin{array}{c}\text { resembled hyaline-like } \\
\text { cartilage with abundant GAG } \\
\text { content. No bone formation or } \\
\text { overgrowth was observed } \\
\text { Macroscopically, cells + } \\
\text { hydrogel produced better } \\
\text { cartilage formation than } \\
\text { hydrogel only or untreated } \\
\text { controls. Regenerated tissue } \\
\text { was smooth and type II } \\
\text { collagen rich }\end{array}$ \\
\hline
\end{tabular}

NA: not applicable; NS: not stated.

MEK/ERK, protein kinase $\mathrm{C}$, and $\mathrm{PI} 3 \mathrm{~K} / \mathrm{AKT}$ ) and/or transcription factors, resulting in altered gene expression. Genes related to proliferation and differentiation are common targets of fibroblast growth factor 2 (FGF-2), which has been utilized for BMSC expansion [7], while insulin-like growth factor 1 has been applied to chondrogenic differentiation of peripheral blood (PB) cells [8] and to the repair of cartilage defects in rabbits [9]. Members of the TGF- $\beta$ superfamily, which include TGF- $\beta 1$ and BMPs 2,4 , and 7 , have been shown to influence the development of cartilage [10] but may skew differentiation towards hypertrophic chondrogenesis and endochondral ossification [11], and TGF- $\beta$ has been linked to cancerous progression in humans [12]. Alternatively, growth differentiation factor 5 has been shown to regulate the differentiation of articular chondrocytes [11] at least in part through inhibition of the BMP4 pathway [13].

Methods for the isolation and preparation of stromal cell populations are not standardized. Indeed, the method of isolation and preparation and the degree of ex vivo manipulation vary widely between laboratories and donor tissue source. Generally, tissue samples are harvested in sterile conditions, and cells are isolated with by different methods (enzymatic digestion or direct culture). Subsequently, cells are cultured in vitro with different conditions. The most popular method to induce chondrogenesis consists in of pellet culture with conditioned medium, which is enriched with insulin, dexamethasone, ascorbic acid, sodium pyruvate, and growth factors, such as TGF- $\beta$ s or BMPs [14]. Chondrogenesis is then confirmed by the analysis of the extracellular matrix (production of GAGs) and by gene expression of cartilaginous markers (i.e., collagen type II, Sox-9).

The choice of scaffold material is significant as the $3 \mathrm{D}$ microenvironment is important for the correct growth and differentiation of cells $[5,15-18]$. This microenvironment includes not only the materials which constitute the scaffold and their characteristics (such as porosity [19], rigidity [18], and biodegradability [16]) but also the in vitro culture conditions (media formulations, as well as both hydrostatic and mechanical forces $[20,21]$ and oxygen levels [22] that cells are exposed to).

Thus, growth factors and scaffolds are often combined with cells for regenerative purposes. For cartilage repair, several cell sources are already available and others are rapidly emerging; the aim of this manuscript is to provide an overview of recent developments in the field, with a particular focus on stem cells.

\section{Terminally Differentiated Cells or Multipotent Cells for Cartilage Repair}

Articular chondrocytes have been extensively used in the past years for autologous chondrocyte transplantation. However, the use of articular chondrocytes is limited by several factors: morbidity at the harvest site, the requirement of a second surgical procedure, and cell dedifferentiation due to in vitro expansion [4, 23-25], necessitated by the limited number of harvestable cells. Alternative sources of differentiated chondrocytes have been investigated, and recently, in a first-inhuman trial, autologous nasal septum chondrocytes were used for the repair of full-thickness articular cartilage defects of the knee [26]. At 2-year follow-up, the changes in a range of clinical scores (IKDC, KOOS pain, KOOS symptoms, KOOS function in daily living, KOOS sport, and KOOS quality of life, relative to preintervention) were positive and the safety of the procedure was confirmed [26]. A phase II clinical trial (NCT01605201) is currently underway to confirm these data.

Stem cells are a cell source of vast potential, which can be isolated from a range of different tissues. These cells constitute a self-renewing population, which can undergo multilineage differentiation [27]. Pluripotent embryonic stem cells derive from the fertilization of the egg, and they can differentiate into any of the three germ layers (endoderm, mesoderm, or ectoderm); thus, they possess the potential to differentiate into any cell lineage. The role of these cells for tissue engineering has been investigated since the late '90s; however, along with induced pluripotent stem cells (iPSCs), the potential tumourigenicity and ethical issues have limited their use in clinical practice (with the notable exception of umbilical cord-derived stem cells $[28,29])$. Conversely, adult postnatal stem cells can be more easily utilized for tissue engineering. These cells have a limited self-renewal and multilineage potential $[27,30,31]$, but they can be isolated from individuals of any age without the ethical dilemmas of embryonic stem cells. The term "mesenchymal stem cell” (MSC) [32] describes a specific subpopulation of adult stem cells on the 
basis of established "minimal criteria" identified by the International Society for Cellular Therapy (ISCT) $[33,34]$ including several cell-surface markers, adherence to plastic culture dishes, and the potential to differentiate into chondrogenic, osteogenic, myogenic, adipogenic, and tenogenic lineages. Cell populations conforming to these criteria can be isolated from several tissues: bone marrow, synovium, adipose tissue, periosteum, peripheral blood, and umbilical cord blood, as well as from the inner part of cartilage of the knee. It must, however, be pointed out that often, these cell populations which are labelled "stem cells" would be more accurately described as stem cell-containing populations. Frequently, the multipotency and self-renewal capacity of these cells are not reported despite the existence of simple tests to do so, such as the colony-forming assay (CFU). The number of actual stem cells isolated from tissue can vary enormously depending on the age of the patient, the technique used for isolation, and the source tissue [31]. The omission of this data makes it challenging to assess the true role of the stem cell as opposed to stromal cells in these studies and to make meaningful comparisons between different studies [35]. Finally, the term "MSC" is sometimes used with no additional information as to the tissue of origin, while stromal cell populations isolated from the bone marrow or adipose tissue, for example, may both conform to the ISCT criteria for "MSCs"; they differ at the epigenetic [36] and phenotypic levels [37, 38] making the inclusion of this information crucial.

The chondrogenic potential of numerous stem cells has been analysed with regard to their possible use in tissue engineering. Probably, the most obvious source of stem cells to regenerate cartilage tissue is cartilage itself, and many studies have sought to isolate and harness the regenerative power of cartilage-resident stem/progenitor cells, some with great success [39-41] (see Table 1). Early studies followed from the illustration of the multilineage potential of BMSCs [27] culminate at the end of the last century with the demonstration of the exclusive and stable differentiation of clonal BMSC populations into chondrocytes [41]. Since then, researchers have capitalised the diversity of tissues from which stem/progenitor cells can be extracted.

Hereafter, we will singularly describe the different tissue sources of stem cells (Figure 1).

2.1. Cartilage. Tissue engineering strategies utilizing autologous cartilage-derived stem/progenitor cells have been attempted since the late 1980s [42-45]. The largely acellular character of cartilage [44] combined with the scarcity of progenitors has been a hurdle to its use; however, some success has been seen using the cells resident in the articular cartilage of the knee $[42,45]$ and the jaw [39]. The advantage of chondrocytes and cartilage-resident cells is their ability to survive in the hypoxic environment found in the wound/implant. Successful results have also been reported using cells taken from the nasal septum [26, 46-48].

The articular cartilage of the knee is a thin layer of largely acellular connective tissue that protects and facilitates the movement of the joints [44]. Due to the low number of resident progenitor cells and challenges in defining the characteristics of the cartilage stem/progenitor cell [1], cartilage isolates have proven unconducive to in vitro cartilage production and any in vitro manipulation must be checked for unintended subsequent osteogenesis or tumourigenesis after implantation.

Recently, resident cartilage progenitor cells isolated from autologous cartilage tissue were shown to form tissue with the characteristics of hyaline cartilage when implanted ectopically in a mouse model; this was supported by data from high-density 2D cultures [39]. These cells were expanded in vitro and implanted in the knees of patients on a collagen scaffold. Patients reported significant improvements (using both IKDC and Lysholm scoring systems); importantly, MRI indicated that the implants covered the defect site and that no sign of hypertrophy was present; histological examination of a subset of implants showed no calcification, inflammation, or vascularisation. In addition to the improved clinical scores, 14 of 15 patients resumed sports activities within 1 year of the intervention, indicative of the practical value of this technique for improving patient quality of life.

Another study overcame the paucity of resident fibrocartilage stem cells (FCSC) within the jaw articular cartilage through prolonged in vitro culture [37]. Animal studies showed that a single FCSC was capable of generating a cartilage template that was remodelled into bone and a bone marrow space, including the haematopoietic microenvironment, without exogenous stimulation from osteogenic scaffolds (such as hydroxyapatite), Matrigel or factors, such as BMPs. This would seem to be great news for bone tissue engineers, but not so great for cartilage regeneration as formation of bone within the articulation is hardly an ideal outcome. However, the authors describe the mechanism by which the pool of resident FCSCs is maintained, though the inhibition of WNT signalling by sclerostin. Indeed, application of sclerostin favoured the differentiation of FCSCs into mature chondrocytes and aided cartilage repair in a rabbit model of cartilage injury [37].

The potential of cells from the nasal septum cartilage for tissue engineering applications was hinted at by basic studies from 2011 to 2012 [46, 48]. Through in vitro experiments and mouse studies, the inherent chondrogenic potential of nasal chondrocytes (NCs) was shown to be similar to that of matched BMSCs with NCs undergoing chondrogenesis in pellet culture without stimulation from either TGF- $\beta$ or BMPs [46]. Significantly, NCs retained their chondrogenic abilities for far longer, until passage 35 , in line with observations that NCs displayed lower levels of senescence markers than BMSCs [48] which would indicate that NCs could be advantageous for tissue engineering strategies that call for multiple rounds of ex vivo expansion. Dedifferentiated NCs have been shown to have greater clonogenic potential (over 3 -fold more) and to proliferate faster that articular chondrocytes [38]. Unlike BMSCs, NCs were not susceptible to adipogenic induction $[46,48]$, possibly due to the significantly higher levels of BMP2 mRNA in NCs [48]. In vivo, NCs displayed no tumourigenicity or signs of metastasis in mice after 4 months, and clinical data show that autologous ex vivoexpanded NCs filled the defect and had no signs of delamination after a similar period of time [38]. 

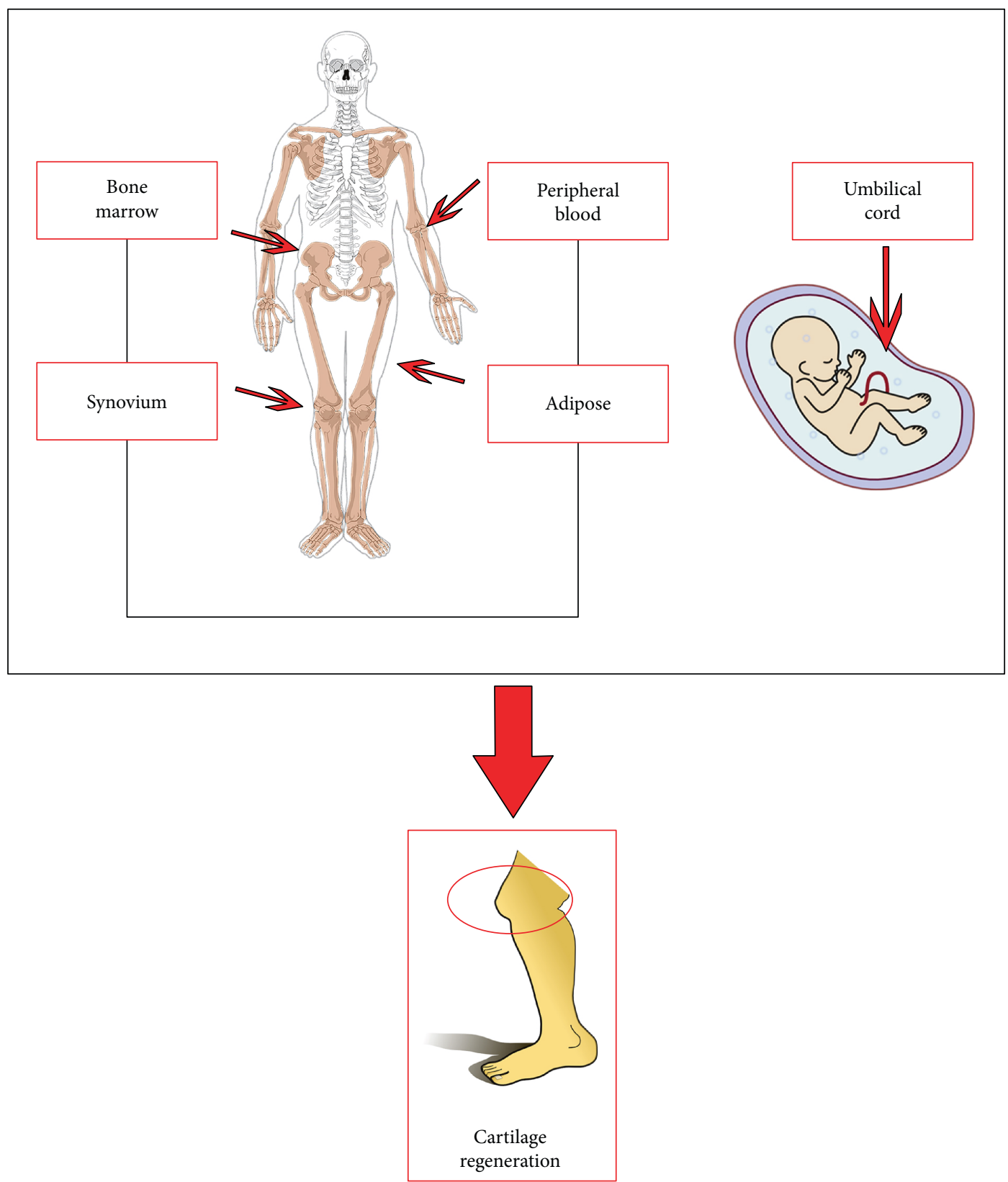

Figure 1: Stem cell sources for cartilage repair.

2.2. Bone Marrow. Substantial clinical information is available on the suitability of bone marrow stromal cells (BMSCs) for cartilage tissue engineering. From initial results showing the potential for cartilage repair [41] to multiple clinical trials [45, 49-54], there is ample evidence to illustrate the applicability of BMSCs to cartilage defect repair. The majority of studies have focused on the use of autologous cells $[45,49-51,53,54]$; however, there are also instances of successful application of allogeneic stem cell preparations to cartilage repair [52].

Removal of the bone marrow is usually achieved by aspiration from the iliac crest of the pelvis. While this is less invasive than some other methods of harvesting cells, the number of stem/progenitor cells obtained is not high and some form of expansion is often performed to obtain sufficient cell numbers. Aside from the concerns about the loss of cell multipotency during 2D cell culture [55], this remains the standard method for expansion of BM stromal cell samples. In some cases, the 2D expanded cell population is then embedded or seeded on a scaffold which provides rigidity and form, before being implanted at the defect site: the choice of scaffold material is not trivial and may influence the differentiation of the embedded cells [56]. The efficacy of 2D expansion followed by implantation on a cartilage-based scaffold has been demonstrated in the lab and in the clinic $[45,49,51$, $53,54]$ with follow-up times up to 11 years [53]. Clinically scaffold-based BMSC implantation resulted in significant improvements in various indicators of quality of life and joint function, including increased mobility and reduction of pain. Although not all patients are willing to undergo second-look 
arthroscopy to assess cartilage formation and coverage, some data exists which shows that some defects were filled with fibrocartilage [49]. Scaffold-free administration of BMSCs expanded in vitro to form a "cell sheet" has also been shown to be effective in an animal model of cartilage defects at 12 weeks [7]. Here, FGF-2, in combination with chondrogenic factors, was noted to increase chondrogenic differentiation as well as cell growth [7]. Intra-articular (i.a.) injection of BMSCs alone $[57,60,61]$ or with additional materials (such as hyaluronic acid (HA)) [59] has been applied to cartilage repair in clinical studies. The results were mostly positive, with an improvement in articular cartilage and meniscal repair noted in patients treated with BMSCs as opposed to controls (when analysed by IKDC, Tegner, and Lysholm scores, as well as MRI and MOCART scores in addition to evaluations of pain and quality of life) $[50,54]$.

Owing to the low frequency of stem/progenitor cells within the BM and the period of time required for in vitro expansion (typically several weeks), an alternate approach has been used for bone marrow aspirate concentrate (BMAC) $[49,50]$. This technique has produced mixed results for the treatment of both osteoarthritis (OA) and cartilage defects in the knee. Gobbi and colleagues describe a case series with significant improvements in multiple scoring matrices (Tegner, Marx, Lysholm, VAS, IKDC subjective, and KOOS scores: $P>0.001)$ at 41 months postoperation (postop), relative to the same tests prior to the intervention [49]. On the other hand, Shapiro et al., in a randomised controlled trial for the treatment of bilateral $\mathrm{OA}$, injected patients with either saline or BMAC, with follow-up at 6 months only to find that the level of pain relief afforded was similar in both treatment and control groups [50]. An additional technique involves the in vitro use of FGF-2 to rapidly expand autologous BMSCs to the point where it is feasible to generate a scaffold-free osteochondral implant thus partially overcoming the often limiting number of BMSCs obtainable from patients [7].

Caution must be exercised when using cells derived from the BM for cartilage repair, as the cells that generate hyaline cartilage are distinct from the growth plate chondrocytes found in the BM which form hypertrophic cartilage that is then remodelled into bone [13,57-60]. Also, there is evidence suggesting that the differentiation and colonyforming potential of BMSCs decrease with donor age, a potential hurdle for autologous use in the elderly [61].

Future prospects for the use of BMSCs for cartilage engineering include the application of 3D printing technologies to tissue engineering with various groups reporting on the fabrication of 3D scaffold materials [62-64]. Recently, the concept has been taken to the next logical step, and a mixture of viable BMSCs and various polymers was used to create a 3D ECM containing live cells which survived in vivo and expressed markers of chondrocytic differentiation [62].

2.3. Synovium. It has been shown, via lineage tracing, that articular chondrocytes derive from synovial joint progenitors, or interzone cells [57], which do not contribute to the growth plate and thus to the formation of bone though endochondral ossification. This represents an advantage in the field of cartilage tissue engineering as heterotopic ossification is to be avoided. The development of articular chondrocytes, as opposed to hypertrophic chondrocytes, has been shown to be influenced by the TGF- $\beta$ pathway, as opposed to signalling through BMP4 [13].

Synovial cells have been assessed for their use in cartilage repair, although few clinical data are published. Basic studies in animal models however are promising showing that synovium-derived cells represent a valid option for continuous study. Mak et al. found a population of synovial sca- $1^{+}$ progenitor cells with inherent chondrogenic potential which were shown to increase cartilage repair 4 weeks after i.a. injection in a mouse model [65], while Baboolal and colleagues present results suggesting that HA present in the synovial fluid inhibits the initial interaction between stromal cells and cartilage [66]. These last results may be significant as inhibition of early binding events could be deleterious for the repairing potential of injected cells. Indeed, a series of studies from researchers at Tokyo Medical and Dental University in Japan have illustrated the significance of early cell attachment through the use of their "local adherent technique" whereby a short period (10 minutes) of joint immobility is sufficient for improved attachment of synoviumderived stem cell populations and results in significantly improved healing in both nonhuman animals and clinical studies [67-69].

2.4. Adipose Tissue. In 2001, Zuk et al. demonstrated that adipose-derived stromal/stem cells (ADSCs) can be differentiated into chondrocytes, adipocytes, and osteoblasts [70] paving the way for a host of studies into the application of autologous ADSCs in regenerative medicine [71-73]. As in the neighbouring field of bone regenerative medicine, where proponents of BMSC-based or ADSC-based cell therapies cite the merits of either tissue versus the other [40], the same is true for cartilage engineering. There are parallels between the fields, and the various merits are somewhat overlapping. On the one hand, the accessibility and abundance of adipose tissue are an obvious advantage over the limited volumes that can be collected from the bone marrow, with less comorbidity to boot. ADSCs were shown to have a higher clonogenic potential and lower tendency towards osteogenic differentiation [74]. On the other hand, the regenerative potential of ADSCs versus BMSCs, millilitre for millilitre, appears to favour the use of the less abundant, harder to access, BMSCs. Indeed, in vitro comparisons of the chondrogenic potential of human BMSCs and ADSCs have concluded that BMSCs possess a greater chondrogenic potential than matched ADSCs $[75,76]$. An important paper from 2010 highlighted the potential pitfalls of comparing BMSC and ADSC for cartilage regeneration using in vitro culture conditions that were optimised to one cell type, at the expense of the other [71]. Nevertheless, the same authors concluded that while both ADSCs and BMSCs underwent chondrogenic differentiation, it was the latter that produced the greater amount of matrix over a greater range of culture conditions.

In recent years, a number of clinical studies have focused on the chondrogenic potential of ADSCs [71, 74-77]. Jo et al. compared various doses of autologous ADSCs administered 
via i.a. injection in both phase I and II trials and concluded that better results positively correlated with higher numbers of ADSCs [77]. The highest dose (100 million cells) produced smooth glossy white cartilage that was well integrated with the subchondral bone, comparable to native cartilage and free of calcification at 6 months postinjection. Importantly, in the highest dose, the defect underwent significant reduction in volume paralleled by an increase in cartilage volume in some cases at 6-month follow-up; lower doses of ADSCs did not produce such positive results. In contrast to these findings, a recent clinical trial (NCT01585857) reported that the lowest dose (2 million cells) of autologous ADSCs injected i.a. for knee OA produced the greatest improvement in pain and function tests using the Western Ontario and McMaster Universities Osteoarthritis Index (WOMAC), although this seems to be primarily due to the differences in baseline pain and function seen in the low-dose group [78]. Indeed, little difference is seen at later time points [78].

Further positive results were reported using the autologous stromal vascular fraction (SVF) harvested from the buttocks of 30 patients which were then reinjected intraoperatively to assess the clinical effect on elderly patients with knee OA [72]. Assessment at 2 years showed improvements in motor function, cartilage healing, and reduced pain. After 2 years, the average Lysholm score increased (from 54 to 74), the VAS pain score decreased (from 4.7 to 1.7 ), and the KOOS increased in all categories at all postoperative time points. The same group followed up the previous study with a level II, prospective comparative study to compare the clinical and radiologic efficacy of ADSCs harvested from the SVF, with fibrin glue and microfractures (MFX) versus MFX alone in 80 patients with knee cartilage defects [73]. The outcomes at 24 months suggest that the addition of ADSCs to MFX protocols could significantly reduce OA pain (reflected in improved MOCART and KOOS scores). The authors reported no significant effects of ADSCs on other matrices measuring daily activity and quality of life.

2.5. Peripheral Blood. Cells isolated from the peripheral blood and activated using a combination of the CXCR4 antagonist, AMD3100, and granulocyte colony-stimulating factor have been noted to conform to the criteria defining "MSCs" [79, 80] as laid out by the ISCT. In vitro studies using rabbit peripheral blood cells (PBSCs) have shown that not only are these cells substantially more accessible than the corresponding BM-derived cells but that they also possess a greater chondrogenic and adipogenic differentiation potential in in vitro assays [79]. In the same in vitro tests, BMSCs had a greater osteogenic and proliferative capacity while implantation of both BMSCs and PBSCs produced similar chondrogenic results in an in vivo cartilage defect model.

In humans, PBSCs have produced different results when applied to cartilage repair. In a trial comparing 5 weekly injections of HA only or HA plus PBSCs after arthroscopic subchondral drilling for chondral lesions, improvements were noted at 24 months using the IKDC score $(P=0.8)$, using MRI inspection $(P=0.013)$, and using the ICRS score (109-point increase, $P=0.022$ ) [81]. It would be interesting to see further studies expanding an essential "cells versus no cells" experiment to include the effects of other stem cells, such as ADSCs or BMSCs. An extension of the above study by the same group repeated the i.a. injections of $\mathrm{HA} \pm$ PBSCs weekly for 5 weeks and again at 6,12, and 18 months after arthroscopic subchondral drilling in addition to openwedge high tibial osteotomy [82]. Assessment of cartilage repair was carried out by histology (ICRS II scoring system) and by second-look arthroscopy indicating that the technique including PBSCs produced cartilage rich in proteoglycans and collagen which closely resembled native cartilage with no adverse effects reported.

2.6. Umbilical Cord/Umbilical Cord Blood. Another emerging source of stem cells for tissue regeneration is the umbilical cord; with specific regard to cartilage repair and regeneration, several recent reports have highlighted the potential for these cells in the clinic [83-85]. In a recent case report, autologous umbilical cord blood cells (UBSCs) in a HA hydrogel were implanted in $5 \mathrm{~mm}$ diameter and $5 \mathrm{~mm}$ deep drilled holes in the lateral femoral condyle. Assessment was at 1 and 5.5 years and showed improvements in VAS (from 46 preop to 8 and 12 at 1 and 5.5 years postop, resp.), IKDC (63.22 preop to 85.02 and 85.5 at 1 and 5 years postop), and WOMAC scores (25 preop to 2 and 4 at 1 and 5 years postop) [86]. Encouragingly at 1 year, second-look arthroscopy revealed no bone formation or bone exposure at the articular surface which was covered with smooth firm hyaline cartilage. MRI at 1 and 5.5 years showed that the defect was filled, that there was smooth integration with the surrounding tissue, and that the repair was maintained over time. In a larger cohort of patients $(n=7)$ assessed at 1,3 , and 7 years postintervention, human allogeneic UBSCs mixed with a HA hydrogel were evaluated for cartilage repair in the femoral condyle [87]. Human UBSCs as with stem cells from other sources have been used allogeneically on the basis of their reputed immunomodulatory properties $[84,88]$. Ha et al. used human UBSCs in a hydrogel to examine the repair potential of osteochondral defects in a minipig model and noted no adverse effects, no infection, and no rejection after 12 weeks [83]. Additionally, the UBSC-treated defects, in contrast to the untreated controls, contained GAG-rich cartilage with better integration with the surrounding tissue; the defects which received human UBSCs also did better on the ICRS scoring system.

\section{Conclusions}

The issue of degenerated cartilage will remain a pressing medical need as the world population ages. Tissue engineering represents a valid alternative to current techniques, which can offer temporary or partial relief, but is far from ideal. As illustrated in this review, a wide variety of tissues have been examined for their potential suitability for cartilage regeneration or replacement. Each tissue has different advantages in terms of invasiveness, cell yield, cell proliferation, and chondrogenic potential. Thus, the choice of the best cell source depends on several factors: the intrinsic chondrogenicity, the ease of harvest, and the available cell number. In general terms, it seems that more accessible tissues such as 
adipose, blood, and umbilical cord tissues have the advantage despite their noncartilage origins. An alternative approach involves the use of allogeneic cells or implants made using allogeneic cells which are subsequently decellularised to overcome this blockade.

This would permit the use of allogeneic cells for cartilage repair, but at the expense of the potentially anti-inflammatory effects of live MSCs [89]. Indeed, downregulation of inflammatory cytokines has been reported in cocultures of ADSCs and osteoarthritic chondrocytes or synoviocytes [90]. Moreover, reductions in reported pain following injection of stromal cell populations from BM [91] and adipose tissue [77, 92] have been reported. Thus, live MSCs may have a central role in pain reduction following a cartilage repair procedure.

Existing techniques, such as autologous or allogeneic chondrocyte implantation, can be optimised by drawing upon fresh insights from basic science and by continuing to experiment with new cell populations. Excitement over basic findings must as always be tempered with caution regarding the safety of treating cells with growth factors and hormones prior to implantation. A balance between guiding cells down the desired lineage path and pushing them over the edge towards malignant transformation is crucial; however, there are few reported instances.

The issue of premature differentiation during $2 \mathrm{D}$ in vitro expansion is especially salient when discussing explanted articular chondrocytes, which seem to have limited capacity in this regard. Advances in cell culture techniques such as the application of hypoxic growth chambers, as well as $3 \mathrm{D}$ perfusion culture utilizing bioreactors that recapitulate not only the $3 \mathrm{D}$ in vivo environment but also both hydrostatic and compressive loading [93] found in joints, will be vital to compensate for the low number of progenitors found in articular cartilage. Research into alternate sources of cartilage-forming cells is developing, as illustrated by the range of cell sources covered in this review. Nowadays, autologous mesenchymal cells can already be applied in the clinical settings; in particular, BMSCs or ADSCs can be injected i.a. in case of moderate osteoarthritis with the aim to reduce inflammation and, therefore, pain. In case of focal cartilage lesions, BMSCs can also be used in combination with collagenic membranes to repair the defect. However, the use of MSCs in clinical practice is still limited due to all the issues described above.

Clearly, current methods can generate cartilage in vivo with a great promise for future clinical applications. We report on more than 15 case studies or clinical trials in humans with the majority describing positive findings and no adverse effects with follow-up times extending to double-digit figures. This is enormously encouraging, and as we continue to learn more about the nature of progenitor and stem cell populations, we anticipate that improvements in the production of regenerated cartilage will see increased clinical translation and patient benefit.

\section{Conflicts of Interest}

The authors declare that there is no conflict of interests regarding the publication of this paper.

\section{Abbreviations}

AC: $\quad$ Articular chondrocyte

ADSC: Adipose tissue-derived stromal/stem cell

BM: $\quad$ Bone marrow

BMAC: Bone marrow aspirate concentrate

BMSC: $\quad$ Bone marrow stromal/stem cell

BMP: $\quad$ Bone morphogenetic protein

CFU: Colony-forming unit

ECM: $\quad$ Extracellular matrix

FCSC: $\quad$ Fibrocartilage stem cell

FGF-2: $\quad$ Fibroblast growth factor 2

GAG: Glycosaminoglycan

HA: Hyaluronic acid

i.a.: Intra-articular

iPSC: $\quad$ Induced pluripotent stem cell

IKDC: International Knee Documentation Committee

ISCT: International Society for Cellular Therapy

KOOS: $\quad$ Knee Injury and Osteoarthritis Outcome Score

MFX: $\quad$ Microfracture

MOCART: Magnetic resonance observation of cartilage repair tissue

MRI: $\quad$ Magnetic resonance imaging

MSC: $\quad$ Mesenchymal/medicinal stem/stromal cell

NC: $\quad$ Nasal chondrocyte

OA: Osteoarthritis

PB: $\quad$ Peripheral blood

PBSC: $\quad$ Peripheral blood stromal/stem cell

RA: $\quad$ Rheumatoid arthritis

SVF: $\quad$ Stromal vascular fraction

TGF- $\beta$ : Transforming growth factor-beta

WOMAC: Western Ontario and McMaster Universities Osteoarthritis Index

VAS: $\quad$ Visual analogue scale.

\section{References}

[1] C. Karlsson, H. Stenhamre, J. Sandstedt, and A. Lindahl, "Neither Notch1 expression nor cellular size correlate with mesenchymal stem cell properties of adult articular chondrocytes," Cells, Tissues, Organs, vol. 187, no. 4, pp. 275-285, 2008.

[2] P. Zedde, S. Cudoni, G. Giachetti et al., "Subchondral bone remodeling: comparing nanofracture with microfracture. An ovine in vivo study," Joints, vol. 04, no. 02, pp. 087-093, 2016.

[3] P. C. Kreuz, M. R. Steinwachs, C. Erggelet et al., "Results after microfracture of full-thickness chondral defects in different compartments in the knee," Osteoarthritis and Cartilage, vol. 14, no. 11, pp. 1119-1125, 2006.

[4] M. M. Caron, P. J. Emans, M. M. Coolsen et al., "Redifferentiation of dedifferentiated human articular chondrocytes: comparison of 2D and 3D cultures," Osteoarthritis and Cartilage, vol. 20, no. 10, pp. 1170-1178, 2012.

[5] E. Cukierman, R. Pankov, D. R. Stevens, and K. M. Yamada, "Taking cell-matrix adhesions to the third dimension," Science, vol. 294, no. 5547, pp. 1708-1712, 2001.

[6] K. Shimomura, W. Ando, Y. Moriguchi et al., "Next generation mesenchymal stem cell (MSC)-based cartilage repair using scaffold-free tissue engineered constructs generated with synovial mesenchymal stem cells," Cartilage, vol. 6, no. 2, pp. 13S-29S, 2015. 
[7] M. Itokazu, S. Wakitani, H. Mera et al., "Transplantation of scaffold-free cartilage-like cell-sheets made from human bone marrow mesenchymal stem cells for cartilage repair: a preclinical study," Cartilage, vol. 7, no. 4, pp. 361-372, 2016.

[8] J. Frisch, P. Orth, A. Rey-Rico et al., "Peripheral blood aspirates overexpressing IGF-I via rAAV gene transfer undergo enhanced chondrogenic differentiation processes," Journal of Cellular and Molecular Medicine, vol. 21, no. 11, pp. 27482758, 2017.

[9] Z. Zhang, L. Li, W. Yang et al., "The effects of different doses of IGF-1 on cartilage and subchondral bone during the repair of full-thickness articular cartilage defects in rabbits," Osteoarthritis and Cartilage, vol. 25, no. 2, pp. 309-320, 2017.

[10] Q. Chen, C. E. Lee, B. Denard, and J. Ye, "Sustained induction of collagen synthesis by TGF- $\beta$ requires regulated intramembrane proteolysis of CREB3L1," PLoS One, vol. 9, no. 10, article e108528, 2014.

[11] A. M. Craft, N. Ahmed, J. S. Rockel et al., "Specification of chondrocytes and cartilage tissues from embryonic stem cells," Development, vol. 140, no. 12, pp. 2597-2610, 2013.

[12] C. Hwangbo, N. Tae, S. Lee et al., "Syntenin regulates TGF- $\beta 1$ induced Smad activation and the epithelial-to-mesenchymal transition by inhibiting caveolin-mediated TGF- $\beta$ type I receptor internalization," Oncogene, vol. 35, no. 3, pp. 389401, 2016.

[13] A. M. Craft, J. S. Rockel, Y. Nartiss, R. A. Kandel, B. A. Alman, and G. M. Keller, "Generation of articular chondrocytes from human pluripotent stem cells," Nature Biotechnology, vol. 33, no. 6, pp. 638-645, 2015.

[14] O. S. Beane and E. M. Darling, "Isolation, characterization, and differentiation of stem cells for cartilage regeneration," Annals of Biomedical Engineering, vol. 40, no. 10, pp. 2079-2097, 2012.

[15] P. D. Benya and J. D. Shaffer, "Dedifferentiated chondrocytes reexpress the differentiated collagen phenotype when cultured in agarose gels," Cell, vol. 30, no. 1, pp. 215-224, 1982.

[16] S. S. Shah, H. Liang, S. Pandit et al., "Optimization of degradation profile for new scaffold in cartilage repair," Cartilage, 2017.

[17] D. A. Wang, S. Varghese, B. Sharma et al., "Multifunctional chondroitin sulphate for cartilage tissue-biomaterial integration," Nature Materials, vol. 6, no. 5, pp. 385-392, 2007.

[18] H. Lv, H. Wang, Z. Zhang et al., "Biomaterial stiffness determines stem cell fate," Life Sciences, vol. 178, pp. 42-48, 2017.

[19] M. M. Nava, L. Draghi, C. Giordano, and R. Pietrabissa, "The effect of scaffold pore size in cartilage tissue engineering," Journal of Applied Biomaterials and Functional Materials, vol. 14, no. 3, pp. 0-9, 2016.

[20] K. A. Roddy, P. J. Prendergast, and P. Murphy, "Mechanical influences on morphogenesis of the knee joint revealed through morphological, molecular and computational analysis of immobilised embryos," PLoS One, vol. 6, no. 2, article e17526, 2011.

[21] J. Schiavi, L. Reppel, N. Charif et al., "Mechanical stimulations on human bone marrow mesenchymal stem cells enhance cells differentiation in a three-dimensional layered scaffold," Journal of Tissue Engineering and Regenerative Medicine, 2017.

[22] S. Agarwal, S. Loder, C. Brownley et al., "Inhibition of Hifl $\alpha$ prevents both trauma-induced and genetic heterotopic ossification," Proceedings of the National Academy of Sciences of the United States of America, vol. 113, no. 3, pp. E338-E347, 2016.
[23] C. Cournil-Henrionnet, C. Huselstein, Y. Wang et al., "Phenotypic analysis of cell surface markers and gene expression of human mesenchymal stem cells and chondrocytes during monolayer expansion," Biorheology, vol. 45, no. 3-4, pp. 513526, 2008.

[24] M. Schnabel, S. Marlovits, G. Eckhoff et al., "Dedifferentiationassociated changes in morphology and gene expression in primary human articular chondrocytes in cell culture," Osteoarthritis and Cartilage, vol. 10, no. 1, pp. 62-70, 2002.

[25] G. J. van Osch, E. W. Mandl, W. J. Marijnissen, S. W. van der Veen, H. L. Verwoerd-Verhoef, and J. A. Verhaar, "Growth factors in cartilage tissue engineering," Biorheology, vol. 39, no. 1-2, pp. 215-220, 2002.

[26] M. Mumme, A. Barbero, S. Miot et al., "Nasal chondrocytebased engineered autologous cartilage tissue for repair of articular cartilage defects: an observational first-in-human trial," Lancet, vol. 388, no. 10055, pp. 1985-1994, 2016.

[27] M. Owen, "Marrow stromal stem cells," Journal of Cell Science. Supplement, vol. 10, pp. 63-76, 1988.

[28] A. I. Caplan, "Mesenchymal stem cells: time to change the name!," Stem Cells Translational Medicine, vol. 6, no. 6, pp. 1445-1451, 2017.

[29] J. E. Dennis, J. P. Carbillet, A. I. Caplan, and P. Charbord, "The STRO-1+ marrow cell population is multipotential," Cells, Tissues, Organs, vol. 170, no. 2-3, pp. 73-82, 2002.

[30] P. Bourin, B. A. Bunnell, L. Casteilla et al., "Stromal cells from the adipose tissue-derived stromal vascular fraction and culture expanded adipose tissue-derived stromal/stem cells: a joint statement of the International Federation for Adipose Therapeutics and Science (IFATS) and the International Society for Cellular Therapy (ISCT)," Cytotherapy, vol. 15, no. 6, pp. 641-648, 2013.

[31] A. I. Caplan, "Mesenchymal stem cells," Journal of Orthopaedic Research, vol. 9, no. 5, pp. 641-650, 1991.

[32] M. Dominici, K. le Blanc, I. Mueller et al., "Minimal criteria for defining multipotent mesenchymal stromal cells. The International Society for Cellular Therapy position statement," Cytotherapy, vol. 8, no. 4, pp. 315-317, 2006.

[33] P. Bianco, X. Cao, P. S. Frenette et al., "The meaning, the sense and the significance: translating the science of mesenchymal stem cells into medicine," Nature Medicine, vol. 19, no. 1, pp. 35-42, 2013.

[34] A. Reinisch, N. Etchart, D. Thomas et al., "Epigenetic and in vivo comparison of diverse MSC sources reveals an endochondral signature for human hematopoietic niche formation," Blood, vol. 125, no. 2, pp. 249-260, 2015.

[35] T. Vinardell, E. J. Sheehy, C. T. Buckley, and D. J. Kelly, “A comparison of the functionality and in vivo phenotypic stability of cartilaginous tissues engineered from different stem cell sources," Tissue Engineering Part A, vol. 18, no. 11-12, pp. 1161-1170, 2012.

[36] J. N. Fisher, G. M. Peretti, and C. Scotti, "Stem cells for bone regeneration: from cell-based therapies to decellularised engineered extracellular matrices," Stem Cells International, vol. 2016, pp. 93525981-9352515, 2016.

[37] M. C. Embree, M. Chen, S. Pylawka et al., "Exploiting endogenous fibrocartilage stem cells to regenerate cartilage and repair joint injury," Nature Communications, vol. 7, p. 13073, 2016.

[38] K. Pelttari, B. Pippenger, M. Mumme et al., "Adult human neural crest-derived cells for articular cartilage repair," Science Translational Medicine, vol. 6, no. 251, article 251ra119, 2014. 
[39] Y. Jiang, Y. Cai, W. Zhang et al., "Human cartilage-derived progenitor cells from committed chondrocytes for efficient cartilage repair and regeneration," Stem Cells Translational Medicine, vol. 5, no. 6, pp. 733-744, 2016.

[40] M. Owen and A. J. Friedenstein, "Stromal stem cells: marrowderived osteogenic precursors," Ciba Foundation Symposium, vol. 136, pp. 42-60, 1988.

[41] M. F. Pittenger, A. M. Mackay, S. C. Beck et al., "Multilineage potential of adult human mesenchymal stem cells," Science, vol. 284, no. 5411, pp. 143-147, 1999.

[42] D. A. Grande, M. I. Pitman, L. Peterson, D. Menche, and M. Klein, "The repair of experimentally produced defects in rabbit articular cartilage by autologous chondrocyte transplantation," Journal of Orthopaedic Research, vol. 7, no. 2, pp. 208218, 1989.

[43] A. Marmotti, D. E. Bonasia, M. Bruzzone et al., "Human cartilage fragments in a composite scaffold for single-stage cartilage repair: an in vitro study of the chondrocyte migration and the influence of TGF- $\beta 1$ and G-CSF," Knee Surgery, Sports Traumatology, Arthroscopy, vol. 21, no. 8, pp. 1819-1833, 2013.

[44] A. J. Sophia Fox, A. Bedi, and S. A. Rodeo, "The basic science of articular cartilage: structure, composition, and function," Sports Health, vol. 1, no. 6, pp. 461-468, 2009.

[45] S. Wakitani, T. Mitsuoka, N. Nakamura, Y. Toritsuka, Y. Nakamura, and S. Horibe, "Autologous bone marrow stromal cell transplantation for repair of full-thickness articular cartilage defects in human patellae: two case reports," Cell Transplantation, vol. 13, no. 5, pp. 595-600, 2004.

[46] R. J. do Amaral, S. Pedrosa Cda, M. C. Kochem et al., "Isolation of human nasoseptal chondrogenic cells: a promise for cartilage engineering," Stem Cell Research, vol. 8, no. 2, pp. 292299, 2012.

[47] M. Mumme, A. Steinitz, K. M. Nuss et al., "Regenerative potential of tissue-engineered nasal chondrocytes in goat articular cartilage defects," Tissue Engineering Part A, vol. 22, no. 21-22, pp. 1286-1295, 2016.

[48] A. Shafiee, M. Kabiri, N. Ahmadbeigi et al., "Nasal septumderived multipotent progenitors: a potent source for stem cell-based regenerative medicine," Stem Cells and Development, vol. 20, no. 12, pp. 2077-2091, 2011.

[49] A. Gobbi, G. Karnatzikos, and S. R. Sankineani, “One-step surgery with multipotent stem cells for the treatment of large fullthickness chondral defects of the knee," The American Journal of Sports Medicine, vol. 42, no. 3, pp. 648-657, 2014.

[50] S. A. Shapiro, S. E. Kazmerchak, M. G. Heckman, A. C. Zubair, and M. I. O'Connor, "A prospective, single-blind, placebocontrolled trial of bone marrow aspirate concentrate for knee osteoarthritis," The American Journal of Sports Medicine, vol. 45, no. 1, pp. 82-90, 2017.

[51] C. T. Vangsness Jr., J. Farr II, J. Boyd, D. T. Dellaero, C. R. Mills, and M. LeRoux-Williams, "Adult human mesenchymal stem cells delivered via intra-articular injection to the knee following partial medial meniscectomy: a randomized, doubleblind, controlled study," The Journal of Bone and Joint Surgery. American Volume, vol. 96, no. 2, pp. 90-98, 2014.

[52] A. Vega, M. A. Martín-Ferrero, F. del Canto et al., "Treatment of knee osteoarthritis with allogeneic bone marrow mesenchymal stem cells: a randomized controlled trial," Transplantation, vol. 99, no. 8, pp. 1681-1690, 2015.

[53] S. Wakitani, T. Okabe, S. Horibe et al., "Safety of autologous bone marrow-derived mesenchymal stem cell transplantation for cartilage repair in 41 patients with 45 joints followed for up to 11 years and 5 months," Journal of Tissue Engineering and Regenerative Medicine, vol. 5, no. 2, pp. 146-150, 2011.

[54] K. L. Wong, K. B. L. Lee, B. C. Tai, P. Law, E. H. Lee, and J. H. P. Hui, "Injectable cultured bone marrow-derived mesenchymal stem cells in varus knees with cartilage defects undergoing high tibial osteotomy: a prospective, randomized controlled clinical trial with 2 years' follow-up," Arthroscopy, vol. 29, no. 12, pp. 2020-2028, 2013.

[55] A. Papadimitropoulos, E. Piccinini, S. Brachat et al., "Expansion of human mesenchymal stromal cells from fresh bone marrow in a 3D scaffold-based system under direct perfusion," PLoS One, vol. 9, no. 7, article e102359, 2014.

[56] A. J. Engler, S. Sen, H. L. Sweeney, and D. E. Discher, "Matrix elasticity directs stem cell lineage specification," Cell, vol. 126, no. 4, pp. 677-689, 2006.

[57] E. Koyama, Y. Shibukawa, M. Nagayama et al., "A distinct cohort of progenitor cells participates in synovial joint and articular cartilage formation during mouse limb skeletogenesis," Developmental Biology, vol. 316, no. 1, pp. 62-73, 2008.

[58] H. M. Kronenberg, "Developmental regulation of the growth plate," Nature, vol. 423, no. 6937, pp. 332-336, 2003.

[59] C. Scotti, E. Piccinini, H. Takizawa et al., "Engineering of a functional bone organ through endochondral ossification," Proceedings of the National Academy of Sciences of the United States of America, vol. 110, no. 10, pp. 3997-4002, 2013.

[60] C. Scotti, B. Tonnarelli, A. Papadimitropoulos et al., "Recapitulation of endochondral bone formation using human adult mesenchymal stem cells as a paradigm for developmental engineering," Proceedings of the National Academy of Sciences of the United States of America, vol. 107, no. 16, pp. 7251-7256, 2010.

[61] G. F. Muschler, H. Nitto, C. A. Boehm, and K. A. Easley, “Ageand gender-related changes in the cellularity of human bone marrow and the prevalence of osteoblastic progenitors," Journal of Orthopaedic Research, vol. 19, no. 1, pp. 117-125, 2001.

[62] M. Costantini, J. Idaszek, K. Szöke et al., "3D bioprinting of BM-MSCs-loaded ECM biomimetic hydrogels for in vitro neocartilage formation," Biofabrication, vol. 8, no. 3, article 035002, 2016.

[63] A. C. Daly, S. E. Critchley, E. M. Rencsok, and D. J. Kelly, “A comparison of different bioinks for 3D bioprinting of fibrocartilage and hyaline cartilage," Biofabrication, vol. 8, no. 4, article 045002, 2016.

[64] J. Jang, T. G. Kim, B. S. Kim, S. W. Kim, S. M. Kwon, and D. W. Cho, "Tailoring mechanical properties of decellularized extracellular matrix bioink by vitamin B2-induced photo-crosslinking," Acta Biomaterialia, vol. 33, pp. 88-95, 2016.

[65] J. Mak, C. L. Jablonski, C. A. Leonard et al., "Intra-articular injection of synovial mesenchymal stem cells improves cartilage repair in a mouse injury model," Scientific Reports, vol. 6, no. 1, p. 23076, 2016.

[66] T. G. Baboolal, S. C. Mastbergen, E. Jones, S. J. Calder, F. P. J. G. Lafeber, and D. McGonagle, "Synovial fluid hyaluronan mediates MSC attachment to cartilage, a potential novel mechanism contributing to cartilage repair in osteoarthritis using knee joint distraction," Annals of the Rheumatic Diseases, vol. 75, no. 5, pp. 908-915, 2016.

[67] H. Koga, M. Shimaya, T. Muneta et al., "Local adherent technique for transplanting mesenchymal stem cells as a potential 
treatment of cartilage defect," Arthritis Research \& Therapy, vol. 10, no. 4, p. R84, 2008.

[68] T. Nakamura, I. Sekiya, T. Muneta et al., "Arthroscopic, histological and MRI analyses of cartilage repair after a minimally invasive method of transplantation of allogeneic synovial mesenchymal stromal cells into cartilage defects in pigs," Cytotherapy, vol. 14, no. 3, pp. 327-338, 2012.

[69] I. Sekiya, T. Muneta, M. Horie, and H. Koga, “Arthroscopic transplantation of synovial stem cells improves clinical outcomes in knees with cartilage defects," Clinical Orthopaedics and Related Research, vol. 473, no. 7, pp. 2316-2326, 2015.

[70] P. A. Zuk, M. Zhu, H. Mizuno et al., "Multilineage cells from human adipose tissue: implications for cell-based therapies," Tissue Engineering, vol. 7, no. 2, pp. 211-228, 2001.

[71] B. O. Diekman, C. R. Rowland, D. P. Lennon, A. I. Caplan, and F. Guilak, "Chondrogenesis of adult stem cells from adipose tissue and bone marrow: induction by growth factors and cartilage-derived matrix," Tissue Engineering Part A, vol. 16, no. 2, pp. 523-533, 2010.

[72] Y. G. Koh, S. B. Jo, O. R. Kwon et al., "Mesenchymal stem cell injections improve symptoms of knee osteoarthritis," Arthroscopy, vol. 29, no. 4, pp. 748-755, 2013.

[73] Y. G. Koh, O. R. Kwon, Y. S. Kim, Y. J. Choi, and D. H. Tak, "Adipose-derived mesenchymal stem cells with microfracture versus microfracture alone: 2-year follow-up of a prospective randomized trial," Arthroscopy, vol. 32, no. 1, pp. 97-109, 2016.

[74] R. Vishnubalaji, M. al-Nbaheen, B. Kadalmani, A. Aldahmash, and T. Ramesh, "Comparative investigation of the differentiation capability of bone-marrow- and adipose-derived mesenchymal stem cells by qualitative and quantitative analysis," Cell and Tissue Research, vol. 347, no. 2, pp. 419-427, 2012.

[75] H. Afizah, Z. Yang, J. H. P. Hui, H. W. Ouyang, and E. H. Lee, "A comparison between the chondrogenic potential of human bone marrow stem cells (BMSCs) and adipose-derived stem cells (ADSCs) taken from the same donors," Tissue Engineering, vol. 13, no. 4, pp. 659-666, 2007.

[76] N. Kohli, K. T. Wright, R. L. Sammons, L. Jeys, M. Snow, and W. E. B. Johnson, "An in vitro comparison of the incorporation, growth, and chondrogenic potential of human bone marrow versus adipose tissue mesenchymal stem cells in clinically relevant cell scaffolds used for cartilage repair," Cartilage, vol. 6, no. 4, pp. 252-263, 2015.

[77] C. H. Jo, Y. G. Lee, W. H. Shin et al., "Intra-articular injection of mesenchymal stem cells for the treatment of osteoarthritis of the knee: a proof-of-concept clinical trial," Stem Cells, vol. 32, no. 5, pp. 1254-1266, 2014.

[78] Y. M. Pers, L. Rackwitz, R. Ferreira et al., "Adipose mesenchymal stromal cell-based therapy for severe osteoarthritis of the knee: a phase I dose-escalation trial," Stem Cells Translational Medicine, vol. 5, no. 7, pp. 847-856, 2016.

[79] W. L. Fu, C. Y. Zhou, and J. K. Yu, “A new source of mesenchymal stem cells for articular cartilage repair: MSCs derived from mobilized peripheral blood share similar biological characteristics in vitro and chondrogenesis in vivo as MSCs from bone marrow in a rabbit model," The American Journal of Sports Medicine, vol. 42, no. 3, pp. 592-601, 2014.

[80] W. L. Fu, Y. F. Ao, X. Y. Ke et al., "Repair of large full-thickness cartilage defect by activating endogenous peripheral blood stem cells and autologous periosteum flap transplantation combined with patellofemoral realignment," The Knee, vol. 21, no. 2, pp. 609-612, 2014.
[81] K. Y. Saw, A. Anz, C. Siew-Yoke Jee et al., "Articular cartilage regeneration with autologous peripheral blood stem cells versus hyaluronic acid: a randomized controlled trial," Arthroscopy, vol. 29, no. 4, pp. 684-694, 2013.

[82] K. Y. Saw, A. Anz, C. S. Y. Jee, R. C. S. Ng, N. Mohtarrudin, and K. Ragavanaidu, "High tibial osteotomy in combination with chondrogenesis after stem cell therapy: a histologic report of 8 cases," Arthroscopy, vol. 31, no. 10, pp. 1909-1920, 2015.

[83] C. W. Ha, Y. B. Park, J. Y. Chung, and Y. G. Park, "Cartilage repair using composites of human umbilical cord bloodderived mesenchymal stem cells and hyaluronic acid hydrogel in a minipig model," Stem Cells Translational Medicine, vol. 4, no. 9, pp. 1044-1051, 2015.

[84] X. Li, L. Duan, Y. Liang, W. Zhu, J. Xiong, and D. Wang, "Human umbilical cord blood-derived mesenchymal stem cells contribute to chondrogenesis in coculture with chondrocytes," BioMed Research International, vol. 2016, pp. 38270573827059, 2016.

[85] Y. B. Park, C. W. Ha, J. A. Kim et al., "Single-stage cellbased cartilage repair in a rabbit model: cell tracking and in vivo chondrogenesis of human umbilical cord bloodderived mesenchymal stem cells and hyaluronic acid hydrogel composite," Osteoarthritis and Cartilage, vol. 25, no. 4, pp. 570-580, 2017.

[86] Y. B. Park, C. W. Ha, C. H. Lee, and Y. G. Park, "Restoration of a large osteochondral defect of the knee using a composite of umbilical cord blood-derived mesenchymal stem cells and hyaluronic acid hydrogel: a case report with a 5-year follow-up," BMC Musculoskeletal Disorders, vol. 18, no. 1, p. 59, 2017.

[87] Y. B. Park, C. W. Ha, C. H. Lee, Y. C. Yoon, and Y. G. Park, "Cartilage regeneration in osteoarthritic patients by a composite of allogeneic umbilical cord blood-derived mesenchymal stem cells and hyaluronate hydrogel: results from a clinical trial for safety and proof-of-concept with 7 years of extended follow-up," Stem Cells Translational Medicine, vol. 6, no. 2, pp. 613-621, 2017.

[88] A. I. Caplan and D. Correa, "The MSC: an injury drugstore," Cell Stem Cell, vol. 9, no. 1, pp. 11-15, 2011.

[89] G. M. van Buul, E. Villafuertes, P. K. Bos et al., "Mesenchymal stem cells secrete factors that inhibit inflammatory processes in short-term osteoarthritic synovium and cartilage explant culture," Osteoarthritis and Cartilage, vol. 20, no. 10, pp. 1186-1196, 2012.

[90] C. Manferdini, M. Maumus, E. Gabusi et al., “Adipose-derived mesenchymal stem cells exert antiinflammatory effects on chondrocytes and synoviocytes from osteoarthritis patients through prostaglandin E2," Arthritis and Rheumatism, vol. 65, no. 5, pp. 1271-1281, 2013.

[91] M. Emadedin, N. Aghdami, L. Taghiyar et al., "Intra-articular injection of autologous mesenchymal stem cells in six patients with knee osteoarthritis," Archives of Iranian Medicine, vol. 15, no. 7, pp. 422-428, 2012.

[92] Y. G. Koh, Y. J. Choi, O. R. Kwon, and Y. S. Kim, "Second-look arthroscopic evaluation of cartilage lesions after mesenchymal stem cell implantation in osteoarthritic knees," The American Journal of Sports Medicine, vol. 42, no. 7, pp. 1628-1637, 2014.

[93] K. Lagana, M. Moretti, G. Dubini, and M. T. Raimondi, “A new bioreactor for the controlled application of complex mechanical stimuli for cartilage tissue engineering," Proceedings of the Institution of Mechanical Engineers Part $H$, vol. 222, no. 5, pp. 705-715, 2008. 

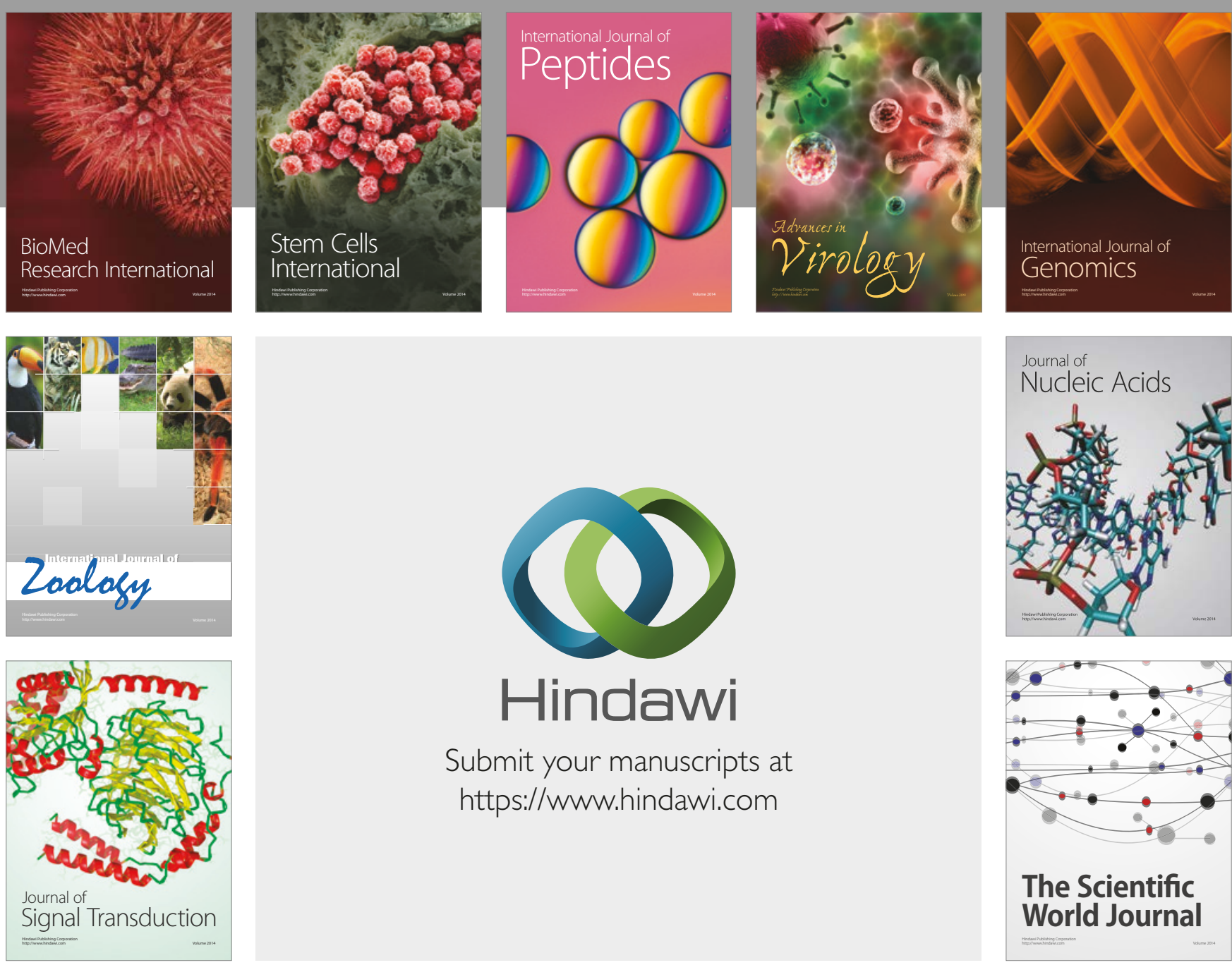

Submit your manuscripts at

https://www.hindawi.com
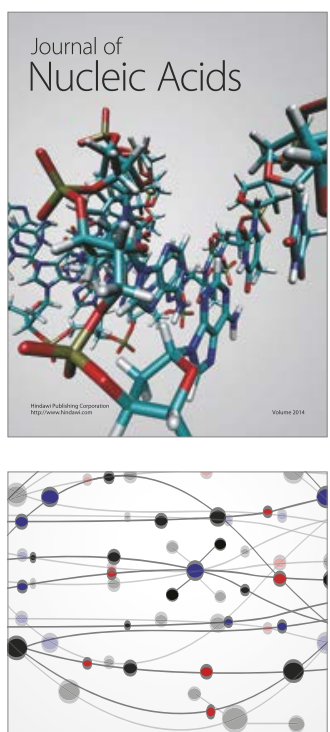

The Scientific World Journal

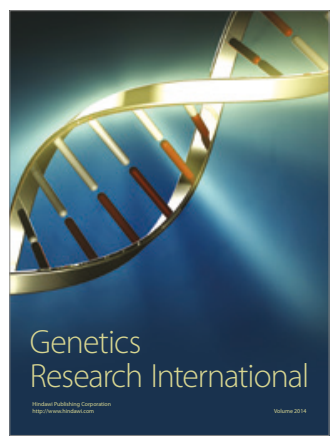

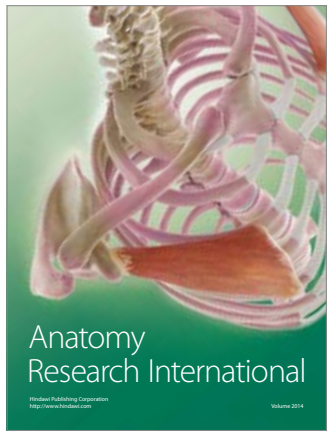

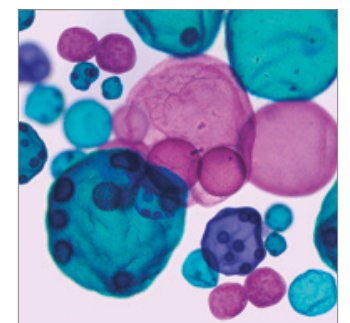

International Journal of Microbiology
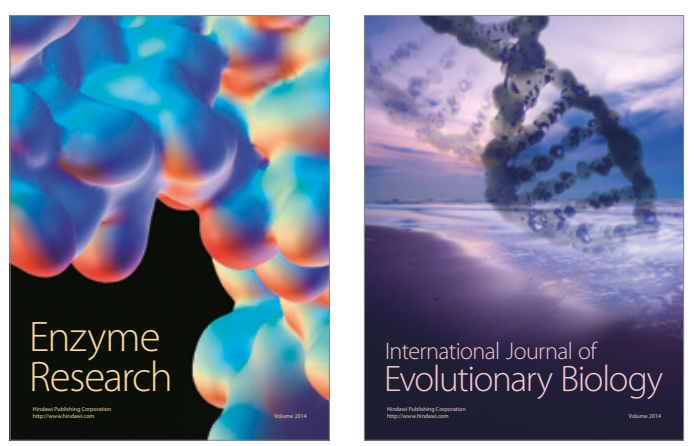
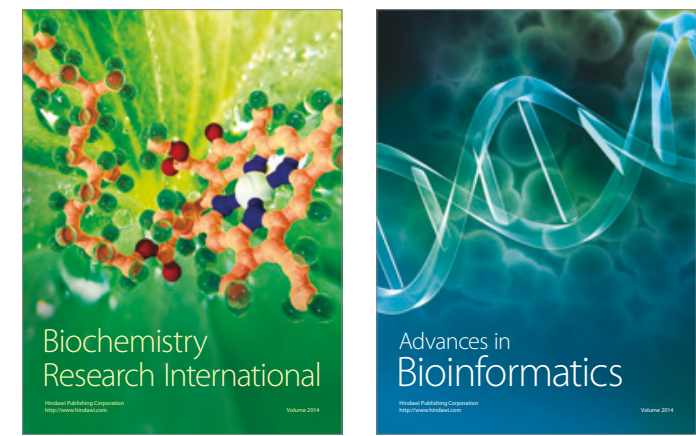

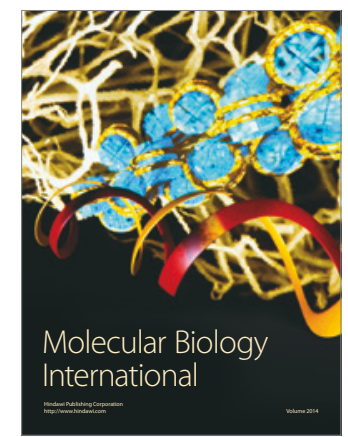

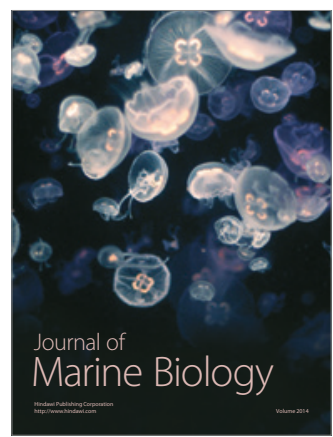

